\title{
WORK-BASED LEARNING INVOLVING THE DUAL EDUCATION ELEMENTS
}

\author{
Natalia Kulalaieva ${ }^{1}$, Snizhana Leu ${ }^{2}$, \\ 1 Candidate in Chemical Sciences, Associate Professor, the Head of the Laboratory for professional training technologies, \\ Institute of vocational education and training of NAES of Ukraine, \\ http://orcid.org/0000-0002-8613-1495, \\ e-mail: culture2016@ukr.net \\ 2 Research scientist the Laboratory for Foreign VET System's Research, Institute of vocational education and training of NAES \\ of Ukraine, \\ http://orcid.org/0000-0001-8616-1005, ResearcherID: I-2465-2016 \\ e-mail: sl-work@i.ua
}

\begin{abstract}
The article analyses the dual education capacity for implementing work-based learning (WBL) for future skilled workers in order to improve the quality and enhance their professional training practice orientation. It is emphasised on information accumulating in the national scientific-pedagogical dimension on dual education elements introducing into future skilled workers professional training. Therefore, the appropriate issues on relevance, expediency, perspective and necessity are actively studied. It is noted that dual education applying is to create real production situations, assure cooperation of students and experienced mentors from enterprises, and demonstrate students' autonomy and initiative in the workplace. It also represents the students' involvement into professional culture and their professional identity, recruitment possibility for the youth of appropriate qualification, strengthening the practical component of professional (vocational) education $(\mathrm{P}(\mathrm{V}) \mathrm{E})$ system, etc.

It provides characteristics for WBL activities and its main forms: work experience, traineeship, work-shadowing, mentoring, apprenticeship, cooperative learning, partnership-based learning, internship or work placement.

The article envisages WBL opportunities in terms of dual education elements implementing. They are the following: 11) vocational training as a means of achieving economic, social and individual goals; 2) vocational training as a task to be carried out in partnership between the government and the business community; 3) joint funding of vocational training; 4) social acceptance of vocational training, the main objective of vocational training; 5) to produce skilled workers with flexible qualifications who are mobile and capable of working in their chosen fields; 6) alternating learning situations in accordance with the dual principle; 7) qualifications of teachers and training personnel; 8) codifying quality standards; 9) balance between standardization and flexibility; 10) complementary programs run by schools or non-business entities; 11) creating a solid basis for decisions and design.
\end{abstract}

Keywords: work-based learning, dual education elements, professional (vocational) education schools, professional training, future qualified workers.

Introduction. The change of Ukraine's socialeconomic development conditions in the framework of Eurointegration, demography, foreign affairs and domestic processes causes the range of transformations in all spheres of sovial life, especially education and industrial ones. The modern professional (vocational) education $(\mathrm{P}(\mathrm{V}) \mathrm{E})$ system reforming is aimed to force its practice orientation, promotes innovative educationindustrial environment creation in $\mathrm{P}(\mathrm{V}) \mathrm{E}$ institutions and active involvement of social partners - the workforce orders. Corresponding, studying the foreign experience on vocational education and training (VET) development and best practices implementing are becoming crucial. The most efficient and productive is the dual form of VET (Denmark, the Netherlands, Germany, Norway, Singapore etc.). Additionally to organisation conditions optimisation, responsibilities sharing it creates the positive circumstances for using all forms of work-based learning (WBL). It is actively promoted in the EU. Thus, taking into account the EU 
countries' national VET systems specifics and gained experience on dual education use, there is a need to implement its elements into education practice of certain countries for strengthening their practiceoriented component of VET. Ukraine is not the exception that is why the following problem is crucial but not enough developed in the Ukrainian dimension.

Materials and methods. It is worth to mention the lack of fundamental scientific works on dual education implementing in qualified workers professional training. The processes of gaining the information of the topic is in place in the scientific and pedagogical sphere. Thus, the issues on up-todatedness costs and benefits, prospects and necessity in the ongoing dual system implementing in Ukraine is actively discussed. For instance, there is an idea that the dual form of education as an example of educationindustrial integration, provides an opportunity to refresh training-practice bases at $\mathrm{P}(\mathrm{V}) \mathrm{E}$ schools, strengthen the teaching employees' professional competence (involving experienced tutors from an enterprise, upskilling $\mathrm{P}(\mathrm{V}) \mathrm{E}$ schools masters at enterprises) (Kushniretsk, Syniura-Rostun, 2017, p. 28). V. Doctorovych (2017, p. 37) emphasises that dual training form implementing in $\mathrm{P}(\mathrm{V}) \mathrm{E}$ schools can help to solve the range of $\mathrm{P}(\mathrm{V}) \mathrm{E}$ system problems, in particular: non-correspondence of vocational training and high-tech industries development; imperfection of models for social partnership mechanisms; law vocational training practice orientation for certain enterprises; inadequate condition of $\mathrm{P}(\mathrm{V}) \mathrm{E}$ schools facilities and resources etc. One of the classifications by German scientists on the elements of the dual training form, suitable for import into VET systems of other countries, together with the SWOT-analysis of their implementation in professional training for future skilled workers of Ukraine were reperesented by N. Kulalaieva (2018). Those elements were also investigated and interpreted via the British and domestic contexts by S. Leu (2018). I. Boychevskaya (2009) summed up the social significance of their introduction for skilled workers professional training. She believes that the well-being of the entire society depends on the way the balance of interests between the employers' needs in new workers and their offer is found.

The research aim is in the analysis of dual form possibilities as the way for realisation the work-based learning for future skilled workers and increasing the quality and practice orientation of their professional training.

Results and discussions. In Ukraine, the interest to dual system has already passed the stage of its studying and is at the stage of its active implementing. In the Law of Ukraine "On Education" the dual form foresees combination of agreement-based at-schools, in-service and other types of training for gaining the qualification (the legislation of Ukraine, 2017). It promotes creating real in-service situations, students and experienced mentors cooperation, student's independence and initiative at their working places, student's perception of professional culture and professional identity, the possibility to fulfill the staff of an enterprise with young workers of appropriate qualification etc. It is important that in Ukraine the dual elements are being implemented into qualifued workers training since 2015. The for purpose implementation is provided for 49 professions (20172020) and in $211 \mathrm{P}(\mathrm{V}) \mathrm{E}$ schools (MoES, 2017; 2018). It is necessary to mention that the Concept on training specialists upon dual form of education (2018) defines three realisation stages before 2023. Firstly, it is planned to develop the appropriate legislation basis (2018-2019), then typical models (2019-2020) and create clusters of dual education (2020-2023). Conversely, in the EU dimension strengthening the VET system practice component is actively promoted via implementing different forms of work-based learning (WBL), especially apprenticeship. The aim is to involve social partners, companies, chambers and VET providers, stimulate innovations and entrepreneurship (BIBB, 2016). In the domestic dimension WBL is interrupted as training for gaining knowledge and skills in terms of direct (modelled) professional activity; is grounded on practice-oriented approaches and helps student to obtain knowledge, skills, form crucial for their professional activity competences (Pukhovska and others, 2017).

The analysis of the EU countries' experience on WBL confirms the possibility to integrate that into the curriculum of general education and fulfil in close cooperation of a training institution and an enterprise or while in-service training. Thus, WBL is widely used for initial, further, advanced trainings or the re-skilling and upskilling ones etc.

In general, the WBL programs are flexible, adaptable and partnership-based. They provide the possibility to obtain complete, partial, additional short and long time courses of professional training. Nevertheless, the need in following courses is caused by the need of an enterprise at a certain stage. WBL assures a win-win situation when a student's needs and the demands of enterprises or sector demands are satisfied. There are several types of WBL.

Work experience covers any experience of a worker in certain sector or profession, mainly volunteer or the one that allows to "feel the professional environment". It is often used as an equivalent of traineeship in the American dimension.

Traineeship is an educational or training program that includes work experience and preparation of young people to their future professional activity with the purpose "to be ready for work". The following WBL 
is perfect for 16-24 year young people to gain necessary skills and experience before starting their professional activity.

Work-shadowing or mentoring in general understanding means a trainee's support while his/her professional activity with detailed study or analysis. It is realised in some stages. The first one is workshadowing and the next one (the higher one) is mentorship. In terms of mentorship the trainee's activity doesn't need permanent control, only observation. It is also used to accelerate the process of adapting the employee to new (changed) working conditions or tasks. The formula for mentoring success is "70/20/ 10 ", where: $70 \%$ - in-service training, $20 \%$ - learning from others and $10 \%$ - classroom education.

Apprenticeship is a systematic long-term study. It combines both in-service and classroom training. It provides for the student the possibility to enter into a contract with the employer and monetary reward. In turn, the employer is responsible for organization the training and ensuring the obtaining of a particular profession (Pukhovskaya, et al., 2016, p. 37). Until recently, it had a rather narrow-profile character and literally meant the kind of practical training that the British called simply "sitting near Tom". Today it is one of WBL leading types in the United Kingdom of Great Britain and Northern Ireland and a full-fledged equivalent of the VET (legislation, regulation, support, coordination and management body - the Institute for Apprenticeship and Technical Education, apprenticeship standards, the network of educational institutions, etc. ) (Leu, 2018). In Germany, apprenticeship is one of the main types of practical training in the conditions of the dual VET system.

Cooperative training involves the accumulation of knowledge, skills, practical experience of all participants in the group and can be used both in an educational institution and in a company or other industrial or educational environment. In the conditions of cooperative education, the "competition of knowledge" is levelled out and the main attention is given to team-work algorithm development in order to achieve the goal.

Learning through partnership can be considered as the next step in cooperative learning. It involves not only the achievement of a common goal, but mutual learning, the development of new strategies and the adoption of common, compromise solutions, etc.

Internship or work placement is the most widespread form of WBL. It is widely used in schools of different types and levels of accreditation. The main purpose of manufacturing practice is to familiarize yourself with the production environment, develop or consolidate certain knowledge and skills in clearly defined terms and conditions. Often used as the equivalent of "work experience" and has a difference that manifests the trainee' decision.

Among the given concepts, the most commonly used are internship, traineeship and apprenticeship. These types of WBL are part of the European legal framework. They appear in national VET legislation, but are in different ways manifested in the organization and content of practical in-plant training (Bundesinstitut fur Berufsbilding, 2016). The practice of using dual education in the developed countries has shown that different types of training are actually implemented on the basis of productive activities. At the same time, the dual education elements are actively implemented into the training of future skilled workers in our country. They also provide opportunities for implementing WBL forms (Euler, 2013) (Table 1).

\section{Table 1}

\section{Possibilities for WBL realisation in terms of dual education elements implementation}

Dual education elements

Broad objective: vocational training as a means of achieving economic, social and individual goals

Vocational training as a task to be carried out in partnership between the government and the business community

Joint funding of vocational training

Social acceptance of vocational training
Possibilities for WBL realisation

Economic productivity and perspective planning of innovations in business Students' social integration and individual development

Joint development of educational standards taking into account professional standards, harmonization of curricula and programs

Independent employers' assessment of students' skills at exams and qualifications

Providing students with jobs at modern leading enterprises

Various social partners involvement in the educational process of educational institutions

Dual training profitability for an enterprise

Attraction of third-party funds (from interested enterprises and business spheres), creation of employers' and trade unions' sector funds in terms of collective agreements

Implementation of professional-practical training directly on the latest equipment of a modern enterprise

Students' adaptation to the conditions of production and recognition of their professional identity

Students' salaries and social package 
Dual education elements

The main objective of vocational training: to produce skilled workers with flexible qualifications who are mobile and capable of working in their chosen fields

\begin{tabular}{ll}
\hline $\begin{array}{l}\text { Alternating learning situations } \\
\text { in accordance with the dual principle }\end{array}$ & $\begin{array}{l}\text { Use of interactive pedagogical technologies (case studies, simulation games, } \\
\text { design, training, critical thinking development, etc.) } \\
\text { A student's diary and continuous discussion of learning outcomes } \\
\text { Skills training in educational and practical centres }\end{array}$ \\
\hline $\begin{array}{l}\text { Qualifications of teachers } \\
\text { and training personnel }\end{array}$ & $\begin{array}{l}\text { Coherence of students' professional activity content and approaches with } \\
\text { changes in conditions and requirements of employers and updating of } \\
\text { production technologies }\end{array}$ \\
& $\begin{array}{l}\text { Improving the quality of pedagogical interaction between mentors and future } \\
\text { specialists }\end{array}$ \\
\hline Codifying quality standards & Simplifying their search and general understanding of the content \\
& $\begin{array}{l}\text { Promoting greater coherence between employers and educational institutions } \\
\text { in developing training and planning documentation }\end{array}$ \\
\hline Balance between standardization & Understanding the range of professional activities within a particular \\
and flexibility & profession \\
& Ensuring the flexibility of students' individual educational trajectories \\
& Variety of education curricula and forms \\
\hline Complementary programs run by & Harmonizing with LLL principles \\
schools or non-business entities & Independent and quick assessment of qualifications acquired by students with \\
& the participation of employers \\
\hline Creating a solid basis for decisions & Systematic monitoring of the labour market \\
and design & VET quality monitoring \\
& Ensuring the compliance of future specialists' training with modern labour \\
& market requirements \\
& VET theory and methodology development \\
\hline
\end{tabular}

Possibilities for WBL realisation

Application of professional skills in a wide range of professional competences

Vocational training at different enterprises

Principle: a teacher and an examiner - different persons
The data analysis results testify the possibility for WBL implementing in terms of dual education. They promote:

$\checkmark$ improvement of pedagogical systems for future skilled workers professional training upon different profile;

$\checkmark$ updating the goals, content, methods, technologies and means of professional training;

$\checkmark$ designing innovative education and production environment for $\mathrm{P}(\mathrm{V}) \mathrm{E}$ schools;

$\checkmark$ creation the mechanisms for public-private partnership in $\mathrm{P}(\mathrm{V}) \mathrm{E}$ schools;

$\checkmark$ functioning of $\mathrm{P}(\mathrm{V}) \mathrm{E}$ schools as independent business entities in the labour market; formatting the common goals and interests for $\mathrm{P}(\mathrm{V}) \mathrm{E}$ schools and enterprises - applicants for bluecollar workers.

Conclusions Thus, WBL is seen as a powerful tool for on the job developing skills and increasing labour productivity. Its extremely high potential contributes to optimising time, effort and resources (human, material and financial). Understanding by educators of its kinds, their features and ways of realisation, in particular, through the introduction of dual education elements, promotes quality improvement and strengthening of the practical orientation for future skilled workers professional training.

\section{List of references}

Бойчевська, І., 2009. Роль системи дуальної освіти у професійній підготовці молоді Німеччини. Порівняльнопедагогічні студіï, [online]. Доступно: <https://nmcpto.sumy.ua/wp-content/uploads/2017/04/Дуальна-система-Німеччини.pdf> [Дата звернення 27 Квітень 2019].

Верховна Рада України. Законодавство України, 2017. Закон України "Про освіту" [online] (Останнє оновлення 19 Січень 2019) Доступно: <https://zakon.rada.gov.ua/laws/show/2145-19> [Дата звернення 30 Травень 2019]. 
Докторович, В. М., 2017. Дуальна система підготовки кваліфікованих робітників як форма інтеграції професійної освіти і виробництва. Теоретико-методичні основи підготовки конкурентоздатних фахівців у контексті сучасного ринку праці: матеріали науково-практичної конференції. Кривий Ріг, Україна 6 Квітень 2017, [оnline] c. 36-39. Доступно: <http://dpl-dnr.at.ua/_ld/0/93 .pdf> [Дата звернення 30 Травень 2019].

Кабінет міністрів України (КМ), 2018. Розпорядження Кабінету міністрів України від 19 вересня 2018 р. № 660-р "Про схвалення Кониепиії підготовки фахівців за дуальною формою здобуття освіти" [online] (Останнє оновлення 30 Жовтень 2018) Доступно: https://zakon.rada.gov.ua/laws/show/660-2018-p\#n9 [Дата звернення 30 Травень 2019].

Кулалаєва, Н., 2018. SWOT-аналіз упровадження елементів дуальної форми навчання у професійну підготовку майбутніх кваліфікованих робітників. Науковий вісник Інституту професійно-технічної освіти НАПН України. Професійна педагогіка, 15, с. 54-60.

Кушнірецька, О. В. та Синюра-Ростун, Н. Р., 2017. Особливості дуальної форми професійної підготовки кадрів у процесах освітньо-виробничої інтеграції. Сучасний стан та пріоритети модернізації фінансовоекономічної системи Украӥни: матеріали VIII Всеукр. науково-практичної конференції студентів, аспірантів та молодих вчених. Львів 23 Листопад 2017, [online] с. 27-30. Доступно: <http://www.lute.lviv.ua/fileadmin/www.lac.lviv.ua/data/ pidrozdily/Naukovi_Vydannya/Docs/2017_ZbirnikFinConf.pdf> [Дата звернення 30 Травень 2019].

Леу, С. О., 2018. Особливості стандартизачї в системі професійної освіти і навчання Великої Британії: методичні рекомендації. Київ: ЦП "Компринт".

Міністерство освіти і науки України (МОН), 2017. Наказ МОН України від 23 червня 2017 р. № 916 "Про впровадження елементів дуальної форми навчання у професійну підготовку кваліфікованих робітників", [online] (чинний) Доступно: https://mon.gov.ua/ua/search?key="Про\%20впровадження\%20елементів\%20дуальної\% 20форми\%20навчання\%20y\%20професійну\%20підготовку\%20кваліфікованих\%20робітників" [Дата звернення 30 Травень 2019].

Міністерство освіти і науки України (МОН), 2018. Наказ Міністерства освіти і науки України від 15 травня 2018 р. № 473 "Про розширення переліку закладів професійної (професійно-технічної) освіти для впровадження елементів дуальної форми навчання", [online] (чинний) Доступно: https://mon.gov.ua/ua/npa/pro-rozshirennyapereliku-zakladiv-profesijnoyi-profesijno-tehnichnoyi-osviti-dlya-vprovadzhennya-elementiv-dualnoyi-formi-navchannya [Дата звернення 30 Травень 2019].

Пуховська, Л. П., Бородієнко, О. В., Леу, С. О., Мельник, О. В., Шимановський, М. М. та Кравець, Ю. І., 2017. Професійні навчальні заклади в краӥнах Свропейського Союзу: практ. посіб. Київ: ІПТО НАПН України.

Пуховська, Л. П., Леу С. О., Радкевич, О. П., Шимановський М. М. та Слатвінська О. А., 2016. Тезаурус професійної освіти і навчання в краӥнах Європейського Союзу. Київ: Інститут професійно-технічної освіти НАПН України.

Bundesinstitut fur Berufsbilding (BIBB), 2016. Poulsen, S. B. and Eberhardt, C., 2016. Approaching Apprenticeship Systems from a European Perspective. Discussion Papers, 4.171, [online] Available at: <https://www.bibb.de/ veroeffentlichungen/en/publication/download/7987> [Accessed 5 Oktober 2018].

Bertelsmann Stiftung (BS), 2013. Euler, D. Germany's dual vocational training system: a model for other countries? [online] Available at: <https://www.bertelsmann-stiftung.de/fileadmin/files/BSt/Publikationen/GrauePublikationen/ GP_Germanys_dual_vocational_training_system.pdf $>$ [Accessed 5 May 2019].

\section{Translated \& Transliterated}

Boichevska, I., 2009. Rol systemy dualnoi osvity u profesiinii pidhotovtsi molodi Nimechchyny [Dual education system role for the youth professional traing in Germany]. Porivnialno-pedahohichni studii [Studies in Comparative Education], [online]. Dostupno: $<$ https://nmcpto.sumy.ua/wp-content/uploads/2017/04/Dualna-systema-Nimechchyny.pdf $>$ [Data zvernennia 27 Kviten 2019], [in Ukrainian].

Verkhovna Rada Ukrainy. Zakonodavstvo Ukrainy [Verkhovna Rada of Ukraine. Legislation of Ukraine], 2017. Zakon Ukrainy "Pro osvitu" [the Law of Ukraine "On Education"] [online] (Ostannie onovlennia 19 Sichen 2019) Dostupno: $<$ https://zakon.rada.gov.ua/laws/show/2145-19> [Data zvernennia 30 Traven 2019], [in Ukrainian].

Doktorovych, V. M., 2017. Dualna systema pidhotovky kvalifikovanykh robitnykiv yak forma intehratsii profesiinoi osvity i vyrobnytstva [Dual system for qualified workers training as an integration form for vocational training and production]. Teoretyko-metodychni osnovy pidhotovky konkurentozdatnykh fakhivtsiv u konteksti suchasnoho rynku pratsi: materialy naukovo-praktychnoi konferentsii [Theory and methods basis for competitive specialists training in terms of modern labour market: materials of scientific and practical conference]. Kryvyi Rih, Ukraina 6 Kviten 2017, [online] s. 36-39. Dostupno: <http://dpl-dnr.at.ua/_ld/0/93 .pdf $>$ [Data zvernennia 30 Traven 2019], [in Ukrainian].

Kabinet ministriv Ukrainy [Cabinet of Ministers of Ukraine] (KM), 2018. Rozporiadzhennia Kabinetu ministriv Ukrainy vid 19 veresnia 2018 r. № 660-r "Pro skhvalennia Kontseptsii pidhotovky fakhivtsiv za dualnoiu formoiu zdobuttia osvity" [Regulation of the Cabinet of Ministers of Ukraine, September 19, 2018 N660-r "On approving the concept for specialists training upon dual form] [online] (Ostannie onovlennia 30 Zhovten 2018) Dostupno: https://zakon.rada.gov.ua/ laws/show/660-2018-r\#n9 [Data zvernennia 30 Traven 2019], [in Ukrainian].

Kulalaieva, N., 2018. SWOT-analiz uprovadzhennia elementiv dualnoi formy navchannia u profesiinu pidhotovku maibutnikh kvalifikovanykh robitnykiv [SWOT-analysis on implementing dual education elements into future skilled workers training]. Naukovyi visnyk Instytutu profesiino-tekhnichnoi osvity NAPN Ukrainy. Profesiina pedahohika [Scientific herald of the Institute of vocational education and training of NAES of Ukraine. Professional Pedagogy], 15, s. 54-60, [in Ukrainian].

Kushniretska, O. V. ta Syniura-Rostun, N. R., 2017. Osoblyvosti dualnoi formy profesiinoi pidhotovky kadriv u protsesakh osvitno-vyrobnychoi intehratsii [Dual education features in the processes of education and production integration]. Suchasnyi stan ta priorytety modernizatsii finansovoekonomichnoi systemy Ukrainy: materialy VIII Vseukr. naukovo-praktychnoi konferentsii studentiv, aspirantiv ta molodykh vchenykh [Modern state and priorities for modernizing 
financing and economy system of Ukraine: materials of VIII all-Ukrainian scientific and practice conference for students, PhD students and scientists]. Lviv 23 Lystopad 2017, [online] s. 27-30 Dostupno: <http://www.lute.lviv.ua/fileadmin/ www.lac.lviv.ua/data/pidrozdily/Naukovi_Vydannya/Docs/2017_ZbirnikFinConf.pdf $>$ [Data zvernennia 30 Traven 2019], [in Ukrainian].

Leu, S. O., 2018. Osoblyvosti standartyzatsii v systemi profesiinoi osvity i navchannia Velykoi Brytanii: metodychni rekomendatsii [Specific nature of standardization in the system of vocational education and training in Great Britain]. Kyiv: TsP "Komprynt", [in Ukrainian].

Ministerstvo osvity i nauky Ukrainy [Ministry of Education and Science of Ukraine] (MON), 2017. Nakaz MON Ukrainy vid 23 chervnia 2017 r. № 916 "Pro vprovadzhennia elementiv dualnoi formy navchannia u profesiinu pidhotovku kvalifikovanykh robitnykiv" [On introducing dual education training form elements in training for qualified workers], [online] (chynnyi) Dostupno: https://mon.gov.ua/ua/search?key="Pro\%20vprovadzhennia\%20elementiv\%20dualnoi\% 20 formy $\% 20$ navchannia\% 20u\%20profesiinu\%20pidhotovku\%20kvalifikovanykh\%20robitnykiv" [Data zvernennia 30 Traven 2019], [in Ukrainian].

Ministerstvo osvity i nauky Ukrainy [Ministry of Education and Science of Ukraine] (MON), 2018. Nakaz Ministerstva osvity i nauky Ukrainy vid 15 travnia 2018 r. № 473 "Pro rozshyrennia pereliku zakladiv profesiinoi (profesiino-tekhnichnoi) osvity dlia vprovadzhennia elementiv dualnoi formy navchannia" [Order of the Ministry of Education and Science of Ukraine May 15, 2018 N473 "On enhancing the list of professional (vocational) education schools for implementing dual training form elements], [online] (chynnyi) Dostupno: https://mon.gov.ua/ua/npa/pro-rozshirennya-pereliku-zakladivprofesijnoyi-profesijno-tehnichnoyi-osviti-dlya-vprovadzhennya-elementiv-dualnoyi-formi-navchannya [Data zvernennia 30 Traven 2019], [in Ukrainian].

Pukhovska, L. P., Borodiienko, O. V., Leu, S. O., Melnyk, O. V., Shymanovskyi, M. M. ta Kravets, Yu. I., 2017. Profesiini navchalni zaklady v krainakh Yevropeiskoho Soiuzu: prakt. posib. [Vocational schools in the EU countries: a practical guide]. Kyiv: IPTO NAPN Ukrainy, [in Ukrainian].

Pukhovska, L.P., Leu, S.O., Radkevych, O.P., Shymanovskyi, M.M. ta Slatvinska, O.A., 2016. Tezaurus profesiinoi osvity i navchannia v krainakh Yevropeiskoho Soiuzu [Thesaurus of vocational education and training in the EU member states]. Kyiv: Instytut profesiino-tekhnichnoi osvity NAPN Ukrainy, [in Ukrainian].

Bundesinstitut für Berufsbilding [The Federal Institute for vocational education] (BIBB), 2016. Poulsen, S. B. and Eberhardt, C., 2016. Approaching Apprenticeship Systems from a European Perspective. Discussion Papers, 4.171, [online] Available at: $<$ https://www.bibb.de/veroeffentlichungen/en/publication/download/7987> [Accessed 5 Oktober 2018], [in German].

Bertelsmann Stiftung (BS), 2013. Euler, D. Germany's dual vocational training system: a model for other countries? [online] Available at: <https://www.bertelsmann-stiftung.de/fileadmin/files/BSt/Publikationen/GrauePublikationen/ GP_Germanys_dual_vocational_training_system.pdf> [Accessed 5 May 2019], [in English].

\title{
Навчання на засадах продуктивної діяльності з використанням елементів дуальної форми здобуття освіти
}

\author{
Наталя Кулалаєва ${ }^{1}$, Сніжана Леу²,
}

1 кандидат хімічних наук, доцент, завідувач лабораторії технологій професійного навчання, Інститут професійнотехнічної освіти НАПН України, http://orcid.org/0000-0002-8613-1495, e-mail: culture2016@ukr.net;

2 науковий співробітник лабораторії зарубіжних систем професійної освіти і навчання, Інститут професійно-технічної освіти НАПН України,

http://orcid.org/0000-0001-8616-1005, ResearcherID: I-2465-2016

e-mail: sl-work@i.ua

Реферат. У статті проаналізовано можливості дуальної форми здобуття освіти як способу реалізації навчання на засадах продуктивної діяльності майбутніх кваліфікованих робітників для поліпшення якості та посилення практико орієнтованості їхньої професійної підготовки. Підкреслено, що у вітчизняному науково-педагогічному просторі відбувається накопичення інформації щодо впровадження елементів дуальної форми навчання в професійну підготовку майбутніх кваліфікованих робітників, а тому активно досліджуються питання актуальності, доцільності, перспективності та необхідності його запровадження. Зазначено, що важливість застосування дуальної форми здобуття освіти полягає у: створенні реальних виробничих ситуацій; співпраці учнів 3 досвідченими наставниками 3 підприємств; прояві учнями самостійності та ініціативності на робочому місці; долучені учнів до професійної культури та усвідомленні ними професійної ідентичності; можливості поповнення кадрового складу підприємств молодими робітниками відповідної кваліфікації; посиленні практичної складової системи професійної (професійно-технічної) освіти тощо.

Охарактеризовано особливості навчання на засадах продуктивної діяльності (work-based learning) та його основні види: досвід роботи (work experience); стажування (traineeship); наставництво (work-shadowing); менторство (mentoring 
рідше mentorship); учнівство (apprenticeship); кооперативне навчання (co-operative); навчання через партнерство (partnership); виробнича практика/навчання (internship чи work-placement).

Показано можливості для реалізації навчання на засадах продуктивної діяльності (work-based learning) через упровадження таких елементів дуальної освіти, як: тривимірне призначення системи професійної освіти (економічні, соціальні, індивідуальні цілі); професійне навчання здійснюється в партнерстві між урядом і бізнесспільнотою; багатоканальне фінансування; соціальне визнання професійної освіти; підготовка мобільних робітничих кадрів; навчання в реальних умовах робітничого середовища; систематичне підвищення кваліфікації педагогічних працівників навчальних закладів та наставників, інструкторів з підприємств; кодифікація стандартів професійної освіти; універсальність та оптимальний зміст стандартів; різноманітні додаткові програми для навчання за дуальною формою; організаційний, науковий та методичний супровід професійної освіти.

Ключові слова: навчання на засадах продуктивної діяльності, елементи дуальної форми здобуття освіти, заклади професійної (професійно-технічної) освіти, професійна підготовка, майбутні кваліфіковані робітники.

Received: 24 May 2019

Accepted: 10 June 2019 